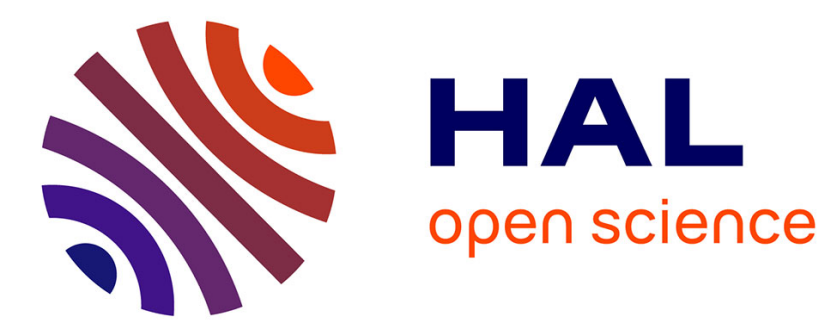

\title{
Multigram Scale-up of the Selective Hydrogenation of alpha-Pinene with Ruthenium Nanoparticles in Water
}

Marion Duval, Sebastien Navarre, Gilles Sagorin, Audrey Denicourt-Nowicki, Alain Roucoux

\section{- To cite this version:}

Marion Duval, Sebastien Navarre, Gilles Sagorin, Audrey Denicourt-Nowicki, Alain Roucoux. Multigram Scale-up of the Selective Hydrogenation of alpha-Pinene with Ruthenium Nanoparticles in Water. ACS Sustainable Chemistry \& Engineering, 2020, 8 (15), pp.5985-5993. 10.1021/acssuschemeng.0c00650 . hal-02797046

HAL Id: hal-02797046

https://hal-univ-rennes1.archives-ouvertes.fr/hal-02797046

Submitted on 15 Jun 2020

HAL is a multi-disciplinary open access archive for the deposit and dissemination of scientific research documents, whether they are published or not. The documents may come from teaching and research institutions in France or abroad, or from public or private research centers.
L'archive ouverte pluridisciplinaire HAL, est destinée au dépôt et à la diffusion de documents scientifiques de niveau recherche, publiés ou non, émanant des établissements d'enseignement et de recherche français ou étrangers, des laboratoires publics ou privés. 


\title{
Multigram scale-up of the selective hydrogenation of $\alpha$-pinene with ruthenium nanoparticles in water
}

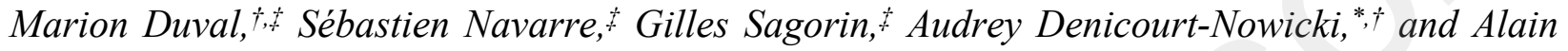
Roucoux* ${ }^{*} \dagger$

† Univ Rennes, Ecole Nationale Supérieure de Chimie de Rennes, CNRS, ISCR - UMR6226, F35000 Rennes, France

\$Dérives Résiniques et Terpéniques, 1220 Route André Dupuy, 40260 Castets, France

Audrey.Denicourt@ensc-rennes.fr; Alain.Roucoux@ensc-rennes.fr

\begin{abstract}
:
This paper presents the successful use of ruthenium nanoparticles, stabilized in water by ammonium surfactants, in the selective hydrogenation of $\alpha$-pinene and the first industrially reported scale-up of this catalyst on a multigram-scale. After designing the nanocatalyst at the lab scale, operational parameters (substrate/metal ratio, pressure and temperature) were identified and optimized in the scale-up. The $\alpha$-pinene hydrogenation process was operated with a $200 \mathrm{~g}$ batch, under 30 bar $\mathrm{H}_{2}$ and at $110^{\circ} \mathrm{C}$, with a complete conversion and a selectivity of $98 \%$ into cis-pinane within $4 \mathrm{~h}$. The catalyst was easily recycled through a liquid-liquid biphasic approach for 5 reaction cycles to achieve a total turnover number (TTON) of 14000.
\end{abstract}




\begin{abstract}
KEYWORDS:
Ruthenium - Nanoparticles - Hydrogenation - $\alpha$-pinene - Water - Scale-up
\end{abstract}

INTRODUCTION

Among cyclic monoterpenes, $\alpha$-pinene constitutes a worldwide available and cheap chemically attractive platform molecule, predominantly present in turpentine with a production of 360,000 tons per year in $2015,{ }^{[1]}$ or as co-product of the paper industry. ${ }^{[2]}$ Moreover, an enhanced production could be expected in the future decades owing to the implementation of wood-fueled biorefineries. ${ }^{[1]}$ Considering the abundance of $\alpha$-pinene in turpentine (60 to $85 \%$ ), the upgrading of this cheap molecule into valuable chemicals represents a wise and relevant strategy. ${ }^{[3]}$

Among the valorization reactions, ${ }^{[4]}$ the hydrogenation of $\alpha$-pinene remains of great interest, affording either cis or trans-pinane (Figure 1), a key intermediate for the production of valuable fragrances or pharmaceuticals, such as rose musk, linalyl acetate or vitamin E. ${ }^{[5]}$ The cis diastereoisomer, which is predominantly obtained during the hydrogenation reaction owing to the presence of the encumbered gem dimethyl bridge, ${ }^{[6]}$ presents a higher reactional activity and thus is highly desirable to produce these intermediates. Therefore, there is still a need to develop scalable catalytic routes with a reduced environmental footprint and an economically viable cost for the industrial production of this valuable cis-enriched isomer.

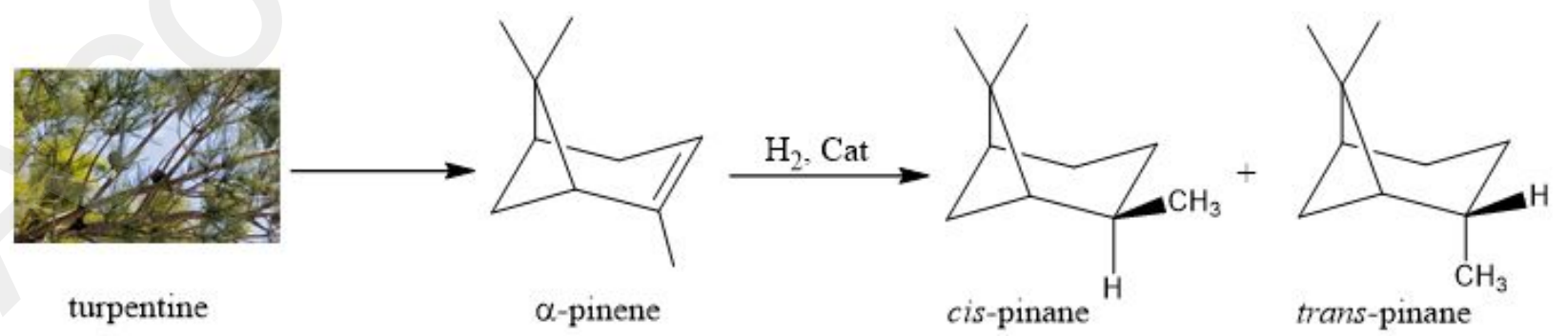

Figure 1. Hydrogenation of $\alpha$-pinene to cis and trans-pinanes 
Evidently, many strategies involving mostly heterogeneous catalysts have been developed to selectively reduce $\alpha$-pinene to $c i s$-pinane, combined with a good reusability, ${ }^{[4]}$ including nickel,,${ }^{[78]}$ ruthenium, ${ }^{[9]}$ palladium ${ }^{[10-11]}$ on different supports. However, these processes still suffer from drastic reaction conditions, with selectivities often inferior to $90 \%$, and are performed in organic solvents, mainly alcohols, with some additives such as $\mathrm{NaOCl}$ or cupric chloride salts to improve their performances. ${ }^{[12]}$

Recently, aqueous suspensions of metal nanoparticles have proved to be relevant catalysts for various applications, owing to their unique properties, affording original surface reactivities associated with a potential recycling under a liquid-liquid biphasic approach. ${ }^{[13]}$ In the literature, ruthenium nanoparticles have been reported for the selective hydrogenation of $\alpha$-pinene to cispinane, stabilized in water with various capping agents such as vitamin $\mathrm{E} T P G S,{ }^{[14]}$ polymers, ${ }^{[15-}$ ${ }^{18]}$ or cyclodextrins. ${ }^{[19]}$ Some nanocatalysts, gathered in Table 1, allowed to achieve quite good catalytic performances, and proved to be reusable. However, only low scale ( $\mathrm{m}<2 \mathrm{~g}$ of substrate) and high catalyst loading have been explored.

Table 1. Overview of the recent applications of ruthenium nanoparticles for $\alpha$-pinene hydrogenation

\begin{tabular}{|c|c|c|c|c|c|c|c|}
\hline Entry & Catalyst & $\begin{array}{l}\text { Reaction } \\
\text { conditions }\end{array}$ & $\begin{array}{c}\text { Substrate } \\
\text { amount }(g)\end{array}$ & $\mathrm{S} / \mathrm{M}$ & $\begin{array}{c}\text { Conv. } \\
(\%)\end{array}$ & $\begin{array}{l}\text { Selectivity } \\
(\%)\end{array}$ & $\begin{array}{l}\text { Number of } \\
\text { recycling runs } \\
\text { (TTON) }\end{array}$ \\
\hline $1^{[14]}$ & $\begin{array}{c}\text { Ru NPs / } \\
\text { TPGS-1000 }\end{array}$ & $\begin{array}{c}5 \text { bar } \mathrm{H}_{2}, 50^{\circ} \mathrm{C} \\
1.5 \mathrm{~h}\end{array}$ & 0.27 & 200 & 99.7 & 98.8 & $10(2000)$ \\
\hline $2^{[16]}$ & $\begin{array}{l}\text { Ru NPs / F127 } \\
\text { copolymers }\end{array}$ & $\begin{array}{c}3 \text { bar } \mathrm{H}_{2}, 40^{\circ} \mathrm{C} \\
3 \mathrm{~h}\end{array}$ & 0.27 & 200 & 91.3 & 99.0 & $7(1400)$ \\
\hline $3^{[15]}$ & Ru NPs / P123 & $\begin{array}{c}7 \text { bar } \mathrm{H}_{2}, 40^{\circ} \mathrm{C} \\
2 \mathrm{~h}\end{array}$ & 0.27 & 200 & 99.9 & 98.9 & $8(1600)$ \\
\hline $4^{[17]}$ & Ru NPs / PVA & $\begin{array}{c}20 \text { bar } \mathrm{H}_{2}, 70^{\circ} \mathrm{C} \\
3 \mathrm{~h}\end{array}$ & 1.36 & 1000 & 99.9 & 98.9 & $8(8000)$ \\
\hline $5^{[18]}$ & $\begin{array}{l}\text { Ru NPs / } \\
\text { cellulose }\end{array}$ & $\begin{array}{c}15 \text { bar } \mathrm{H}_{2}, 75^{\circ} \mathrm{C} \\
5 \mathrm{~h}\end{array}$ & 0.68 & 800 & 80.0 & 100.0 & $7(5600)$ \\
\hline
\end{tabular}


In this paper, we describe the use of easy-to-prepare ruthenium nanoparticles, stabilized in water by ammonium surfactants, for the industrially scaled selective hydrogenation of $\alpha$-pinene in neat water. In a first step, an efficient nanocatalyst was designed at the lab-scale through an evaluation of various reducing agents, the screening of stabilizing agents and the optimization of the water amount. The obtained nanoparticles were fully characterized through adapted physico-chemical techniques. Therefore, the multigram scale-up of the biphasic liquid-liquid $\alpha$-pinene hydrogenation was a good opportunity to evaluate the potential of aqueous suspensions of metallic nanoparticles for future industrial applications.

\section{EXPERIMENTAL SECTION}

\section{Starting Materials}

Ruthenium (III) chloride hydrate $\mathrm{RuCl}_{3} \cdot 3 \mathrm{H}_{2} \mathrm{O}$, and sodium borohydride $\mathrm{NaBH}_{4}$ were purchased from Acros Organics. Cetyltrimethylammonium chloride (CTACl), aqueous solution (30\% wt) of

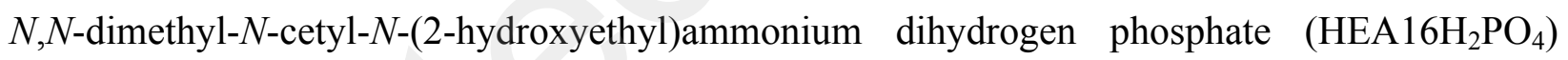
were purchased from Aldrich and were used without further purification. Other $N, N$-dimethyl- $N$ hexadecyl- $N$-(2-hydroxyalkyl)ammonium salts were synthesized according to already reported

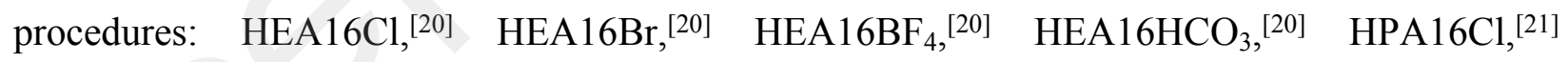
HBA16Cl,[21] THEA16Cl. ${ }^{[22]} \alpha$-pinene (purety 96\%) was provided by Dérivés Résiniques et Terpéniques company (Castets, France). For lab experiments, water was distilled twice before use. For industrial experiments, tap water was used. 


\section{Equipments}

For experiments carried out at lab-scale, stainless steel pressure reactor used was one from Parr Instrument Company (maximal pressure $(\mathrm{PS})=200$ bar, maximal temperature $(\mathrm{TS})=-15^{\circ} \mathrm{C}-350{ }^{\circ} \mathrm{C}$, internal diameter $(\mathrm{Di})=3.3 \mathrm{~cm}$, height $\left.(\mathrm{h})=5.5 \mathrm{~cm}\right)$ equipped with a glass cell $(\mathrm{V}=50 \mathrm{~mL})$, a magnetic stirring and a heating plate. For experiments carried out on larger scale on DRT site, pressure reactor from Parr $\left(\mathrm{V}=1.2 \mathrm{~L}, \mathrm{PU}=350 \mathrm{bar}, \mathrm{TU}=-10^{\circ} \mathrm{C}\right.$ to $350^{\circ} \mathrm{C}, \mathrm{Di}$ $=8.3 \mathrm{~cm}, \mathrm{~h}=24.9 \mathrm{~cm}$ ) was used, equipped with a heating jacket and a hollow shaft mechanical stirrer.

\section{Zeta potential analysis}

Zeta potential measurements were performed by laser Doppler electrophoresis, with Zetasizer Nano ZS90 equipment. Catalytic suspensions of ruthenium(0) were diluted to reach a metal concentration of $7.6 \times 10^{-4}$ mol.L L $^{-1}$ Analyses were performed in a cell (DTS1070, $\left.150 \mu \mathrm{L}\right)$ at $20^{\circ} \mathrm{C}$. The data was processed by the Zetasizer software.

\section{Static multiple light scattering - Turbiscan technology}

Static multiple light scattering analyses were carried out with the Turbiscan Lab technology (Formulaction, Toulouse, France). This apparatus is constituted of a near infrared light source (wavelength $1 / 4880 \mathrm{~nm}$ ), and two synchronized detectors, which all move vertically alongside the cylindrical glass sample cell. The light source head scans the entire height of the sample (up to $55 \mathrm{~mm}$ ), and the detectors acquire transmission and backscattering data every $40 \mu \mathrm{m}$. The measured photon fluxes are calibrated with a non-absorbing scattering standard (calibrated polystyrene latex beads) and a transmittance standard (silicon oil). The temperature of the 
apparatus was regulated at $25.0 \pm 0.1^{\circ} \mathrm{C}$. The nanoparticle suspensions were studied without any dilution and for each one of them a scan was carried out every $4 \mathrm{~h}$, along 7 days.

\section{TEM experiments}

Transmission electron microscopy (TEM) images were recorded with a JEOL TEM 100CXII electron microscope operated at an acceleration voltage of $100 \mathrm{kV}$, with a KeenView camera and the ITEM software (1376x1032 px). The samples were prepared by the addition of a drop of the colloidal suspension on a copper grid coated with a porous carbon film. The size distributions for spherical particles were determined measuring 250 particles, through a manual analysis of enlarged micrographs with Image J software and using Microsoft Excel to generate histograms of the statistical distribution and a mean diameter. High resolution TEM analysis was carried out on a JEOL JEM 2010 UHR electron microscope with lanthanum hexaboride source (LaB6), using CDD camera (Gatan Orius SC1000) and ITEM software (4008 x 2672 pixels).

\section{GC-FID analysis}

Gas chromatography was performed using a Trace GC Ultra (Thermo Scientific) apparatus with a FID detector, equipped with a Thermo Fisher HP5-MS capillary column (30 m, 0.25 i.d., 0.5 f.t.) Parameters were as follows: temperature was increased from $120{ }^{\circ} \mathrm{C}$ to $160{ }^{\circ} \mathrm{C}$ at $5{ }^{\circ} \mathrm{C} / \mathrm{min}$ (maintained $2 \mathrm{~min}$ ) and then from $160{ }^{\circ} \mathrm{C}$ to $220^{\circ} \mathrm{C}$ with a ramp of $20{ }^{\circ} \mathrm{C} / \mathrm{min}$ (maintained $3 \mathrm{~min}$ ). Injector temperature, $250{ }^{\circ} \mathrm{C}$; detector temperature, $250^{\circ} \mathrm{C}$; injection volume $1 \mu \mathrm{L}$, split flow : $16 \mathrm{~mL} / \mathrm{min}$, carrier gas $(\mathrm{He}) 0.8 \mathrm{~mL} / \mathrm{min}$. The final chromatogram was recorded and treated using ChromQuest software. Products identification was performed by comparison of their retention 
times with commercial products. Reaction rate and selectivity were determined by standard calibration with $n$-dodecane as internal standard.

\section{pH measurements}

$\mathrm{pH}$ measurements were performed on the suspension with a Mettler Toledo $\mathrm{pH}$ meter without any dilution.

\section{Synthesis of ammonium-stabilized Ru(0) suspension - Reduction by $\mathrm{NaBH}_{4}$}

To an aqueous solution $(5 \mathrm{~mL})$ of a chosen quaternary ammonium salt ( 2 equiv., $\left.7.6 \times 10^{-5} \mathrm{~mol}\right)$ was added $1 \mathrm{~mL}$ an aqueous solution of sodium borohydride ( 2.5 equiv., $\left.9.5 \times 10^{-5} \mathrm{~mol}\right)$. Then, this solution was quickly added under vigorous stirring to an aqueous solution $(4 \mathrm{~mL})$ of the ruthenium (III) chloride hydrate $\mathrm{RuCl}_{3} \cdot 3 \mathrm{H}_{2} \mathrm{O}$ (1 equiv., $3.8 \times 10^{-5}$ mol) to obtain a colloidal suspension of $\mathrm{Ru}(0)$. The reduction occurred instantaneously and was manifested by a color change from brown to black. The suspension was kept under stirring $12 \mathrm{~h}$ before use.

\section{Synthesis of ammonium-stabilized Ru(0) suspension - Reduction by $\mathrm{H}_{2}$ \\ An aqueous solution $(5 \mathrm{~mL})$ of a chosen quaternary ammonium salt ( 2 equiv., $\left.7.6 \times 10^{-5} \mathrm{~mol}\right)$ was added to an aqueous solution $\left(5 \mathrm{~mL}\right.$ ) of the metallic precursor $\mathrm{RuCl}_{3} \cdot 3 \cdot \mathrm{H}_{2} \mathrm{O}$ (1 equiv., $3.8 \times 10^{-5} \mathrm{~mol}$ ). This mixture was then introduced in an autoclave under $10 \mathrm{bar} \mathrm{H}_{2}$ and $50{ }^{\circ} \mathrm{C}$, during $12 \mathrm{~h}$, to afford a colloidal suspension of $\mathrm{Ru}(0)$. The reduction was manifested by a color change from brown to black.}




\section{Catalytic experiments $(50 \mathrm{~mL}$ reactor)}

In a $50 \mathrm{~mL}$ pressure reactor, $10 \mathrm{~mL}$ of a catalytic suspension $(0.038 \mathrm{mmol}$ of ruthenium $)$ and $\alpha$ pinene $(3.8 \mathrm{mmol}, 0.52 \mathrm{~g})$ were introduced. The autoclave was purged with $\mathrm{H}_{2}$ and pressurized to the given pressure. The reaction was kept at room temperature, under magnetic stirring during the desired reaction time. At the end of the reaction, the reaction products were extracted with diethyl ether $(3 \times 10 \mathrm{~mL})$ and analyzed by GC-FID.

\section{Catalytic experiments $(1.2 \mathrm{~L}$ reactor $)$}

Specified amounts of ruthenium trichloride hydrate $\mathrm{RuCl}_{3} \cdot 3 \mathrm{H}_{2} \mathrm{O}$, stabilizer, water and $\alpha$-pinene were introduced in a $1.2 \mathrm{~L}$ pressure reactor. The autoclave was purged with $\mathrm{H}_{2}$ and pressurized to a given pressure. The reactor could be heated thanks to a water jacket. The reaction was conducted under mechanical stirring with hydrogen circulation thanks to a hollow shaft. At the end of the reaction, the final products were obtained through simple decantation and the supernatant was analyzed by GC-FID.

\section{Recycling procedure $(1.2 \mathrm{~L}$ reactor)}

The hydrogenation reaction was carried out as mentioned above. When complete conversion was reached and after decantation, the organic phase was purged through a pipe and a new batch of substrate was introduced within the reactor. A new reaction cycle could be conducted. This operation was repeated up to five times. 


\section{RESULTS AND DISCUSSION}

\section{Lab-scale optimization}

In an initial set of experiments, the best catalytic system in terms of stability and catalytic performances was defined on a laboratory-scale.

First, ruthenium nanoparticles were synthesized through a bottom-up method, by chemical reduction of the ruthenium(III) chloride hydrate $\left(\mathrm{RuCl}_{3} \cdot 3 \mathrm{H}_{2} \mathrm{O}\right)$ in the presence of $N$, $N$-dimethyl$N$-cetyl- $N$-(2-hydroxyethyl)ammonium chloride (HEA16Cl) as protecting agent with a molar ratio of 2 according to previous results. ${ }^{[23]}$ First, two reduction approaches were evaluated, using either sodium borohydride $\left(\mathrm{NaBH}_{4}\right)$ as a well-known reducing agent (Entry 1, Table 2) for the reduction of metal salts, or dihydrogen $\left(\mathrm{H}_{2}\right)$ as a clean and green agent, ${ }^{[24]}$ classically used for organometallic precursors (Entry 2, Table 2). ${ }^{[25]}$

Both colloidal suspensions were characterized by transmission electron microscopy (TEM) to determine the morphology and the size of the particles, as well as by high resolution transmission electron microscopy (HR-TEM) to better understand the sample atomic structure (Figure 2). The nanoparticles obtained through the reduction by hydride salts $\left(\mathrm{NaBH}_{4}\right)$ were spherical, presenting an average diameter of about $1.75 \mathrm{~nm}$ and a narrow size distribution (Figure $2 \mathrm{a}$ and $2 \mathrm{~b}$ ), while rods with sizes between 2 and $6 \mathrm{~nm}$ were observed for those obtained under dihydrogen (Figure 2c and 2d). Moreover, in both cases, the zeta potential values, measured by electrophoretic light scattering, showed positive values, superior to $+30 \mathrm{mV}$, evidencing highly stable suspensions probably due to the significant electrostatic repulsion (Table 2). ${ }^{[26]}$ 

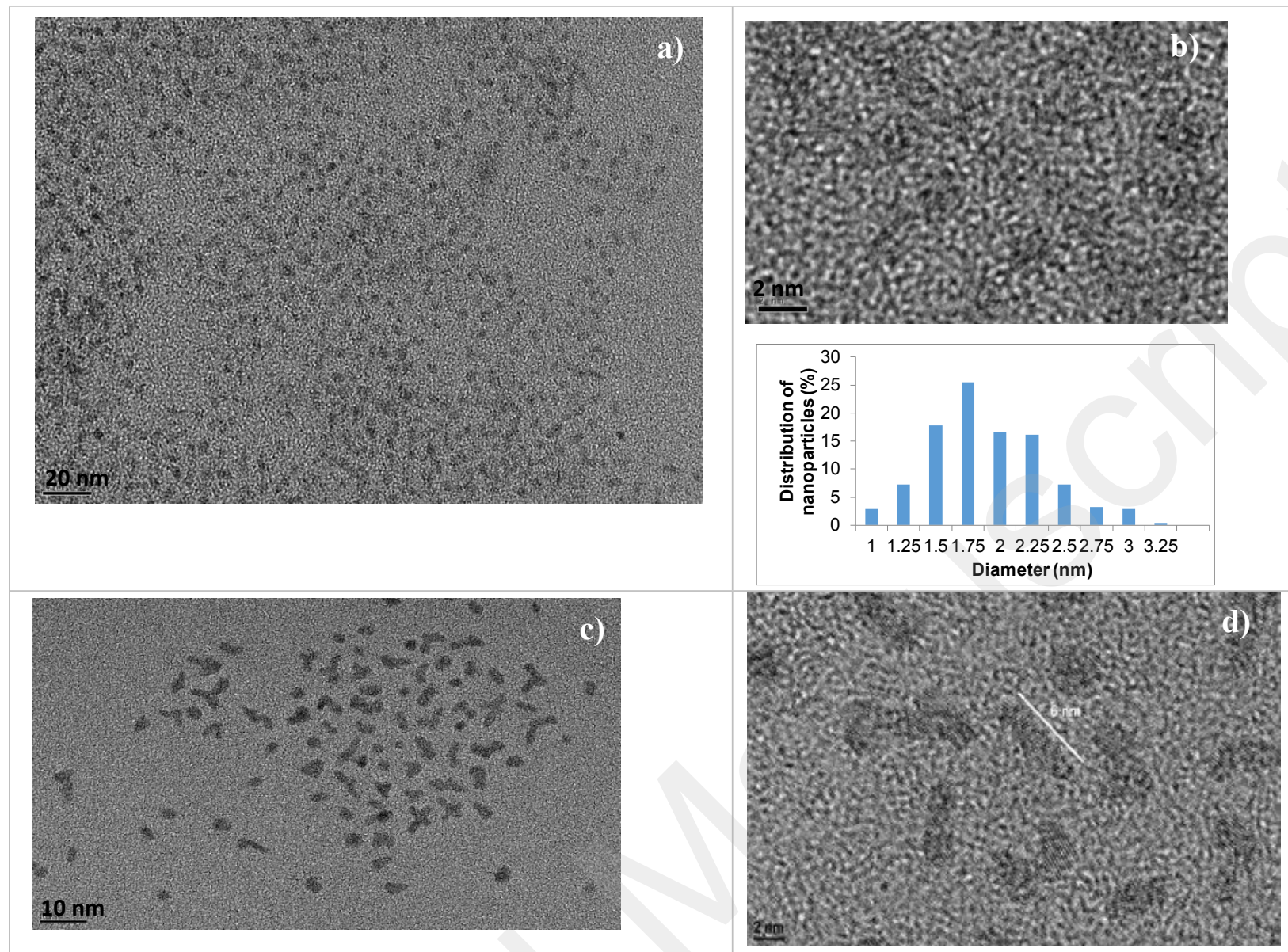

Figure 2. TEM (on the left) and HR-TEM images (on the right) of a) Ru NPs reduced by $\mathrm{NaBH}_{4}$ (magnification $\times 120000$, scale bar $20 \mathrm{~nm}$ ), b) $\mathrm{Ru}$ NPs reduced by $\mathrm{NaBH}_{4}$ (magnification $\times 600000$, scale bar $2 \mathrm{~nm}$ ) with size distribution, c) $\mathrm{Ru}$ NPs reduced by $\mathrm{H}_{2}$ (magnification $\times 200000$, scale bar $10 \mathrm{~nm}$ ) and d) $\mathrm{Ru} \mathrm{NPs}$ reduced by $\mathrm{H}_{2}$ (magnification $\times 600000$, scale bar $2 \mathrm{~nm})$

Both nanocatalysts were evaluated in the hydrogenation of $\alpha$-pinene under 10 bar $\mathrm{H}_{2}$, at room temperature, in water (Table 2). Whatever the catalyst was, a high level of selectivity was achieved. However, the suspension prepared with dihydrogen $\left(\mathrm{H}_{2}\right)$ displayed better kinetics, with a $96 \%$ conversion in 1 h (Entry 2), compared to $84 \%$ with the catalyst synthesized with sodium borohydride (Entry 1). Moreover, dihydrogen was a more appropriate reducing agent for industrial scale-up operations. 
Table 2. Hydrogenation of $\alpha$-pinene. Choice of the reducing agents for the preparation of $\operatorname{Ru}(0)$ nanoparticles ${ }^{\mathrm{a}}$

\begin{tabular}{cccccccc}
\hline Entry & Reducing agent & NP morphology & NP size $(\mathrm{nm})$ & $\mathrm{pH}$ & $\zeta^{\mathrm{c}}(\mathrm{mV})$ & Conv. $^{\mathrm{d}}(\%)$ & Selectivity ${ }^{\mathrm{d}}(\%)$ \\
\hline 1 & $\mathrm{NaBH}_{4}$ & Spheres & 1.75 & 2.1 & +52 & 84 & 98 \\
2 & $\mathrm{H}_{2}$ & Rods & $2-6$ & 1.7 & +57 & 96 & 99 \\
\hline
\end{tabular}

The physico-chemical stability of the suspension was also studied using Turbiscan technology (Formulaction, France), based on the transmitted and backscattered laser light through the sample. This unusual technology enables to detect destabilization phenomena, such as reversible particle migration (sedimentation or creaming), or size variation (coalescence or flocculation). ${ }^{[27-28]}$ Both solutions reduced either by sodium borohydride (Suspension 1) or dihydrogen (Suspension 2) were scanned from the bottom $(0 \mathrm{~nm})$ to the top of the sample $(40 \mathrm{~mm})$ at different time intervals during 7 days (Figure 3). An increase in the backscattered signal was observed on the top of the vial for the suspension 1 (Figure $3 \mathrm{a}, \mathrm{NaBH}_{4}$ ), evidencing a destabilization by creaming, and on the bottom of the sample for the suspension 2 (Figure $3 \mathrm{~b}, \mathrm{H}_{2}$ ), indicating sedimentation. The kinetics of destabilization (Turbiscan stability index (TSI) measurements along time expressed in days) proved that the $\mathrm{Ru} @ \mathrm{HEA} 16 \mathrm{Cl}$ nanoparticle suspension obtained with $\mathrm{H}_{2}$ had a better stability in time (TSI variations $<|0.15|)$ than the other one (TSI variations $>|1.1|)$ (Figure 3c). However, in both cases, TSI values remained low and destabilization phenomena were almost negligible, evidencing a good stability of both suspensions. In the following experiments, dihydrogen was chosen as an eco-responsible and easy-to-use reducing agent at industrial scale, as well as a suitable reagent for one-pot synthesis. 


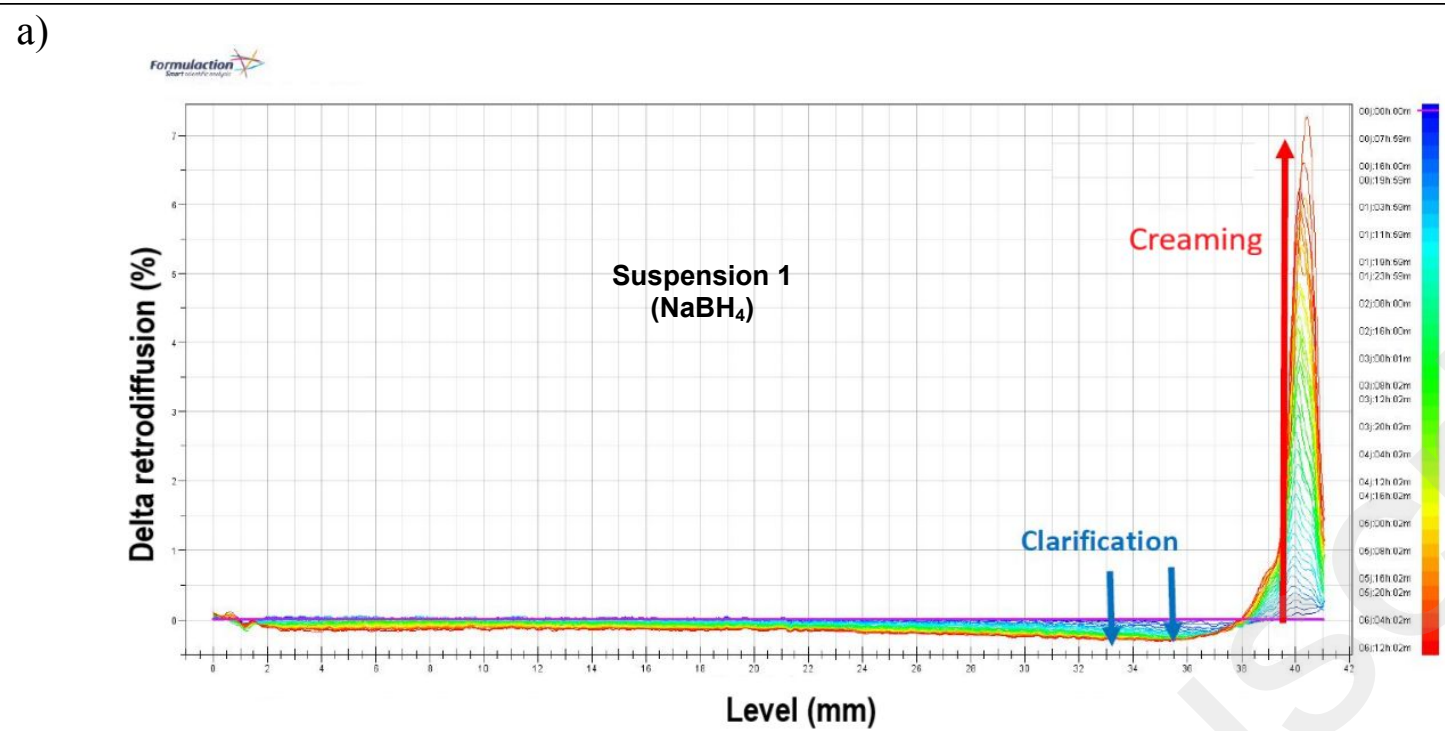

b)

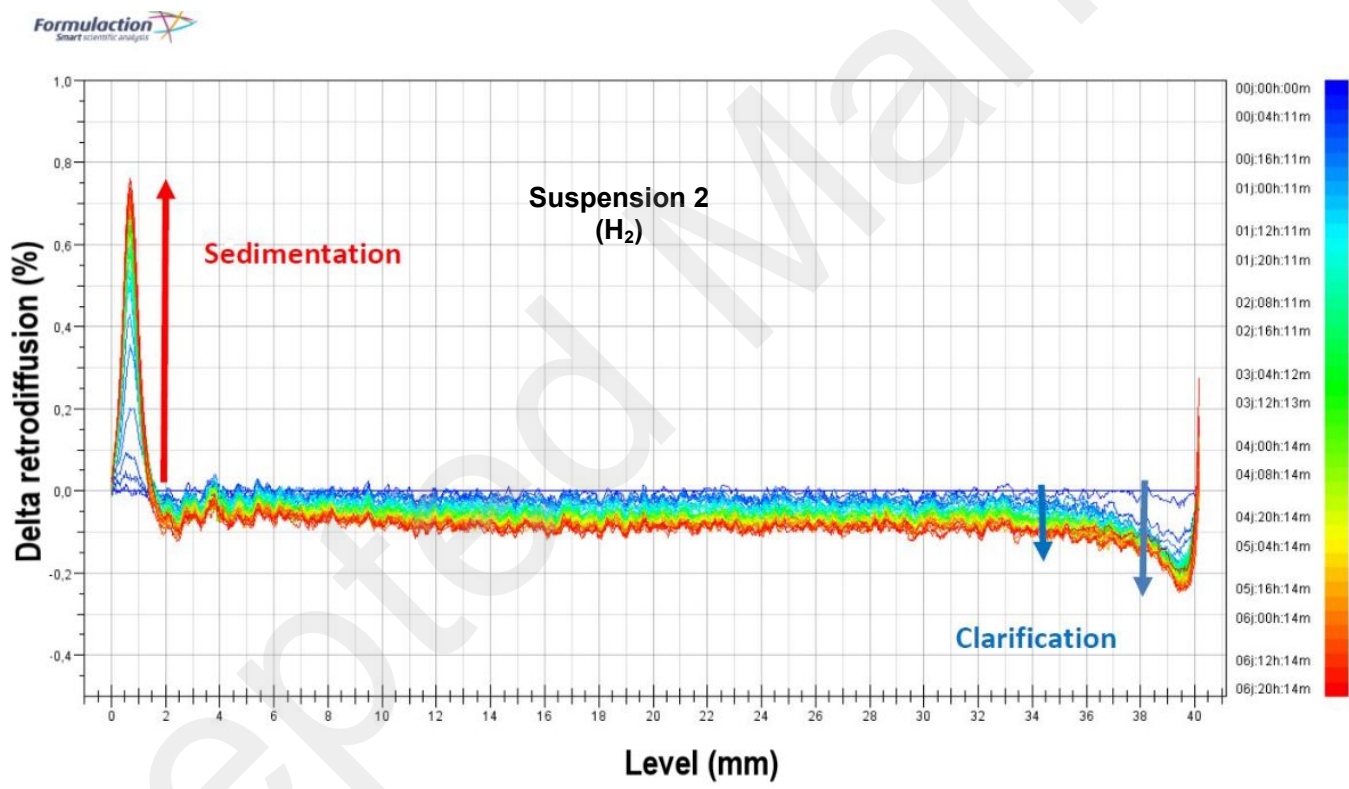


c)

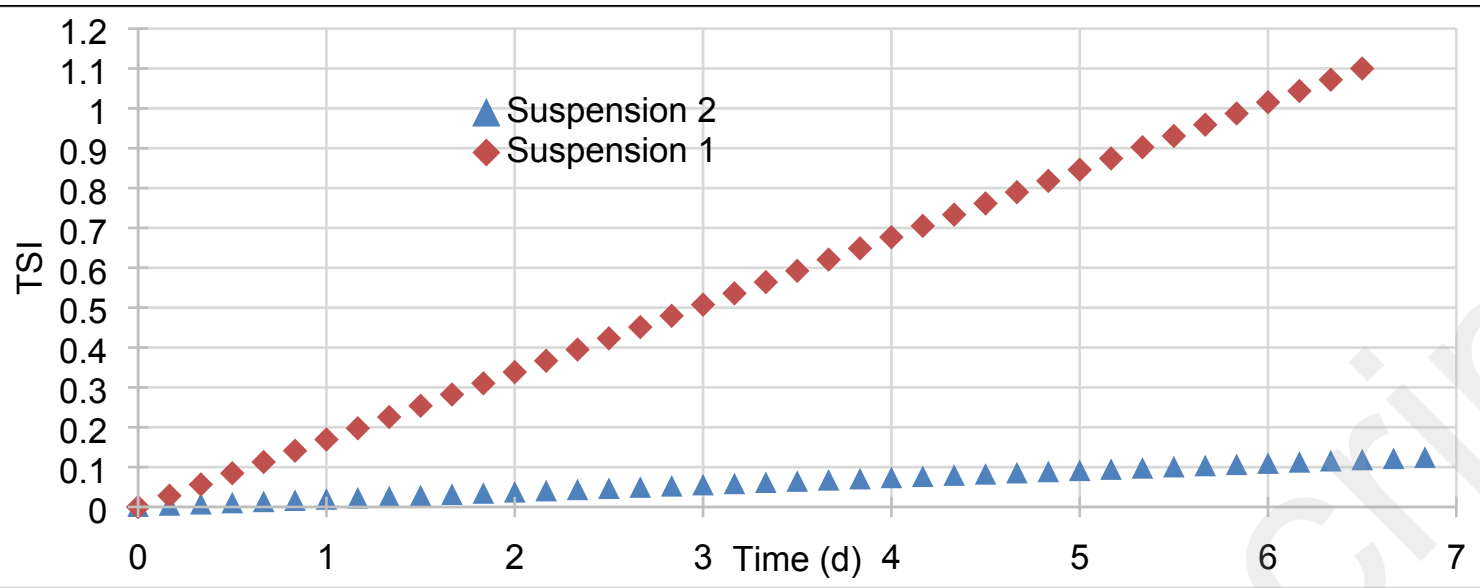

Figure 3. Turbiscan measurements. Evolution depending on time of transmitted and backscattered signals (Delta Retrodiffusion) depending on the sample level in $\mathrm{mm}\left(25^{\circ} \mathrm{C}\right)$ a) For suspension $1\left(\mathrm{NaBH}_{4}\right)$, b) For suspension $2\left(\mathrm{H}_{2}\right)$ and c) Turbiscan Stability Index (TSI) depending on time (day)

Secondly, the influence of various water-soluble capping agents for the ruthenium nanospecies on the catalytic performances was investigated. This choice remains crucial to insure relevant catalytic performances in the nanometer-sized micelles, ${ }^{[29]}$ as well as to maintain the catalyst within the aqueous media. Several ammonium surfactants, that possess a highly hydrophilic monoor poly-hydroxylated polar head combined with a lipophilic sixteen-carbon chain, with diverse counter-ions, were used as capping agents of ruthenium nanoparticles and evaluated in the selective hydrogenation of $\alpha$-pinene at 10 bar $\mathrm{H}_{2}$ and room temperature in water. The results are gathered in Figure 4 and compared to the commercial CTACl surfactant. 


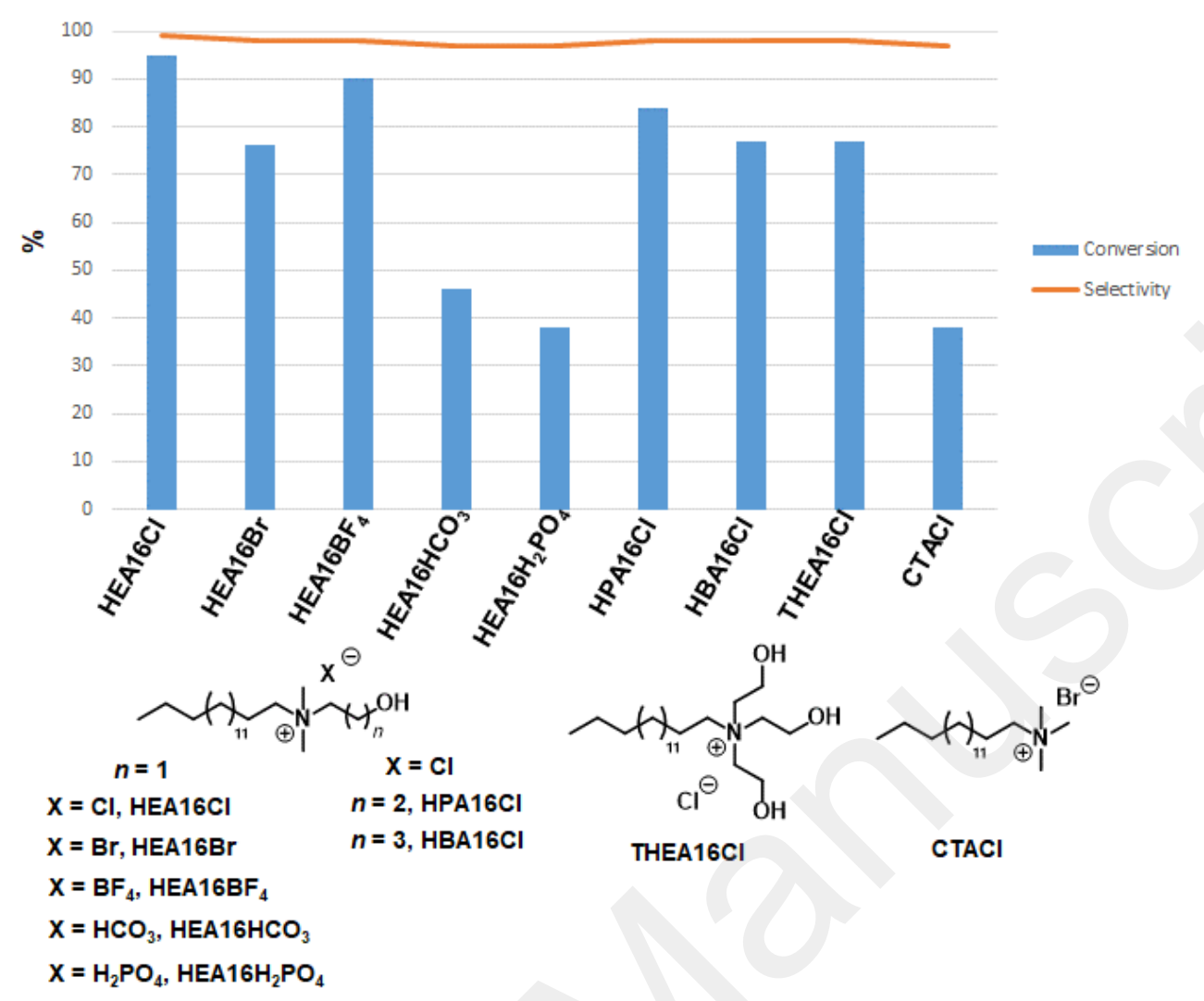

Figure 4. Screening of various surfactants on the catalytic performances in $\alpha$-pinene hydrogenation. Reaction conditions: Ru@capping agent (3.8 $\times 10^{-5}$ mol, 0.01 equiv.), capping agent $\left(7.6 \times 10^{-5}\right.$ mol, 0.02 equiv. $), \alpha$-pinene $\left(0.5 \mathrm{~g}, 3.8 \times 10^{-3}\right.$ mol, 1 equiv. $), 10$ bar $\mathrm{H}_{2}$, $\mathrm{H}_{2} \mathrm{O}(10 \mathrm{~mL})$, r.t., $1 \mathrm{~h}$

First, in most of the cases, compared to the usual CTACl surfactant that led to only $38 \%$ conversion, the hydroxylated surfactants afforded an increased conversion up to $95 \%$. These improved catalytic performances could be attributed to an enhanced water-solubility of the surfactant owing to the hydroxyl function, thus potentially affording a better colloidal protection. Moreover, free micelles of surfactants could improve the solubility of the organic substrate within

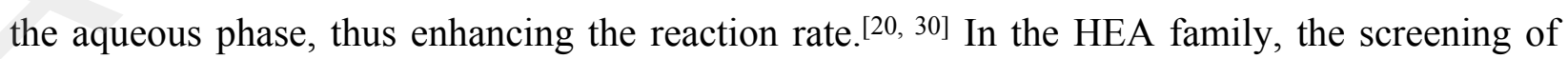
various counter-ions was performed, showing an effect of this parameter on the catalytic activity, in the following order: $\mathrm{Cl}>\mathrm{BF}_{4}>\mathrm{Br}>\mathrm{HCO}_{3}>\mathrm{H}_{2} \mathrm{PO}_{4}$. These results could be attributed to the 
steric hindrance of the adsorbed anion at the metal surface, thus hampering the substrate access to the active species, ${ }^{[31]}$ as well as the coordination strength. ${ }^{[32]}$

To conclude, best results were achieved with HEA16Cl, with $95 \%$ conversion and $99 \%$ selectivity into the targeted cis-pinane. This surfactant possesses a head group of smaller size, and consequently a lower molecular area A. This parameter, defined as the area occupied by the surfactant molecules at the interface, is directly influenced by the steric hindrance of the polar head. Moreover, the HEA16Cl capping agent also displays a higher critical packing parameter (CPP) which indicates a flexible bilayer organization of the micelles and might improve its ability as transfer agent between phases. ${ }^{[33]}$

Finally, the amount of water used in the catalytic reaction was identified as a potential problematic operational parameter in the scale-up, in order to limit the wastewater flow. The concentration of ruthenium in water was increased gradually from $3.8 \mathrm{mM}$ to $12.7 \mathrm{mM}$, with a constant HEA16Cl/Ru molar ratio of 2 (Table 3, entries 1-3), by decreasing the amount of water. Whatever the amount of water was, similar hydrogenation performances were observed with conversion up to $88 \%$ and a selectivity of $99 \%$ for higher metal concentration (Entry 3 ). To meet the requirement of an industrial process, the ruthenium concentration was fixed at $12.7 \mathrm{mM}$ for the following scaleup.

Table 3. Hydrogenation of $\alpha$-pinene. Influence of the water amount ${ }^{\mathrm{a}}$

\begin{tabular}{ccccc}
\hline Entry & Ruthenium concentration $\left(\mathrm{mmol}^{\mathrm{L}} \mathrm{L}^{-1}\right)$ & Water amount $(\mathrm{g})$ & Conversion $^{\mathrm{b}}(\%)$ & Selectivity $^{\mathrm{b}}(\%)$ \\
\hline 1 & 3.8 & 10 & 84 & 98 \\
2 & 7.6 & 5 & 86 & 98 \\
3 & 12.7 & 3 & 88 & 99 \\
\hline
\end{tabular}

${ }^{a}$ Reaction conditions: $\mathrm{Ru}\left(3.8 \times 10^{-5} \mathrm{~mol}, 0.01\right.$ equiv. $), \mathrm{HEA} 16 \mathrm{Cl}\left(7.6 \times 10^{-5} \mathrm{~mol}, 0.02\right.$ equiv. $) \alpha-$ pinene $(0.5 \mathrm{~g}$, $3.8 \times 10^{-3}$ mol, 1 equiv.), 10 bar $\mathrm{H}_{2}, \mathrm{H}_{2} \mathrm{O}$, r.t., 1 h. ${ }^{\mathrm{b}}$ Determined by Gas Chromatography 


\section{Scale-up experiments}

Based on these encouraging results, the hydrogenation of $\alpha$-pinene, catalyzed by the Ru@HEA16Cl catalyst, was performed from 100 to 600 gram scale, using the facilities of the DRT plant. The experiments were conducted in a $1.2 \mathrm{~L}$-reactor, equipped with mechanical stirring and a heating jacket. Moreover, the procedure was simplified, since all the reagents (metallic precursor, surfactant, water and substrate) were simultaneously introduced in the reactor and directly placed under dihydrogen. Thus, the Ru@HEA16Cl nanoparticles were synthesized in situ and controlled by TEM after a catalytic hydrogenation of $\alpha$-pinene (Figure 5 ). They were rather spherical with an average diameter of $2.3 \pm 0.5 \mathrm{~nm}$, and no agglomeration phenomenon was observed after this catalytic reaction.

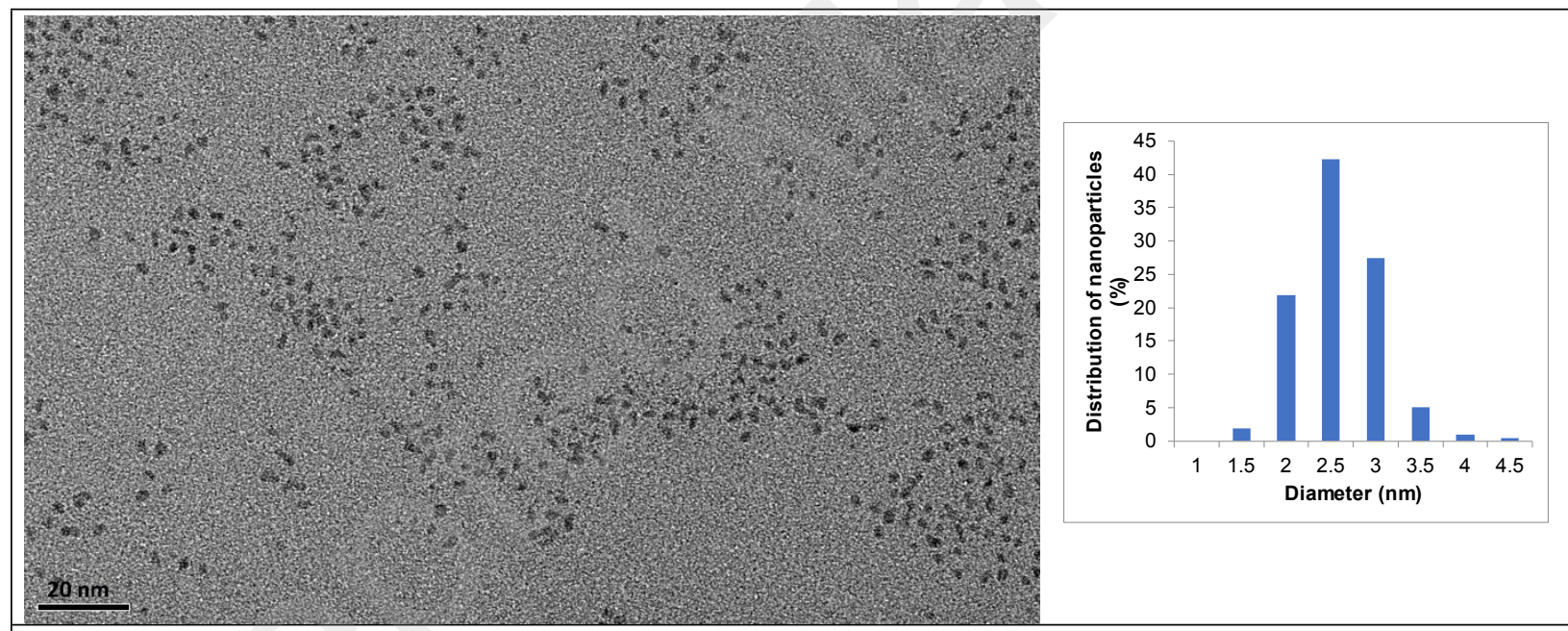

Figure 5. TEM of Ru NPs prepared in situ and after a catalytic hydrogenation reaction (magnification $\times 100000$, scale bar $20 \mathrm{~nm}$ ) with size distribution.

The hydrogenation of $\alpha$-pinene was carried out using the optimized Ru@HEA16Cl catalyst with a metal concentration in water of $12.7 \mathrm{mmol. \textrm {L } ^ { - 1 }}$, under $10 \mathrm{bar} \mathrm{H}_{2}$ and at room temperature, with various substrate/metal ratios. The results are gathered in Table 4 . 
First, while maintaining the same substrate/metal molar ratio and a substrate/water molar ratio of 0.2, a scale-up from $500 \mathrm{mg}$ (Entry $1,50 \mathrm{~mL}$ reactor) to $100 \mathrm{~g}$ (Entry 2, $1.2 \mathrm{~L}$ reactor) of $\alpha$-pinene proved to be feasible by adjusting the process temperature at $50{ }^{\circ} \mathrm{C}$ and the reaction time from 1 to $5 \mathrm{~h}$, with a complete conversion and a selectivity of $99 \%$ in cis-pinane. In a second set of experiments, the catalyst loading, which constitutes a crucial deciding factor in terms of economic profitability, was assessed to meet industrial requirements (Entries 2-5). Lowering the catalyst loading by increasing the substrate/metal molar ratio from 100 to 1000 , while maintaining the $\alpha$ pinene amount, afforded cis-pinane with a 96\% conversion and an excellent selectivity of $99 \%$ after $6.5 \mathrm{~h}$ (Entry 3). However, increasing the $\alpha$-pinene amount, while decreasing the catalyst loading, led to slower reaction kinetics with quite low conversions (inferior to $21 \%$ ) but $99 \%$ of selectivity. These results could be attributed to an increased organic phase (composed of pure $\alpha$ pinene) compared to the aqueous phase, thus slowing the mass transfer of the substrate at the metal surface. To improve the performances of the $\mathrm{Ru} @ \mathrm{HEA} 16 \mathrm{Cl}$ nanocatalyst, the operational conditions, such as the temperature and the pressure, were investigated at a relevant substrate/metal ratio of 3000 (Figure 6). 
Figure 6. Optimization of the reaction parameters of the $\alpha$-pinene hydrogenation with $\mathrm{Ru} @$ HEA16Cl nanocatalyst

a) Influence of the temperature under 10 bar $\mathrm{H}_{2}{ }^{\mathrm{a}}$

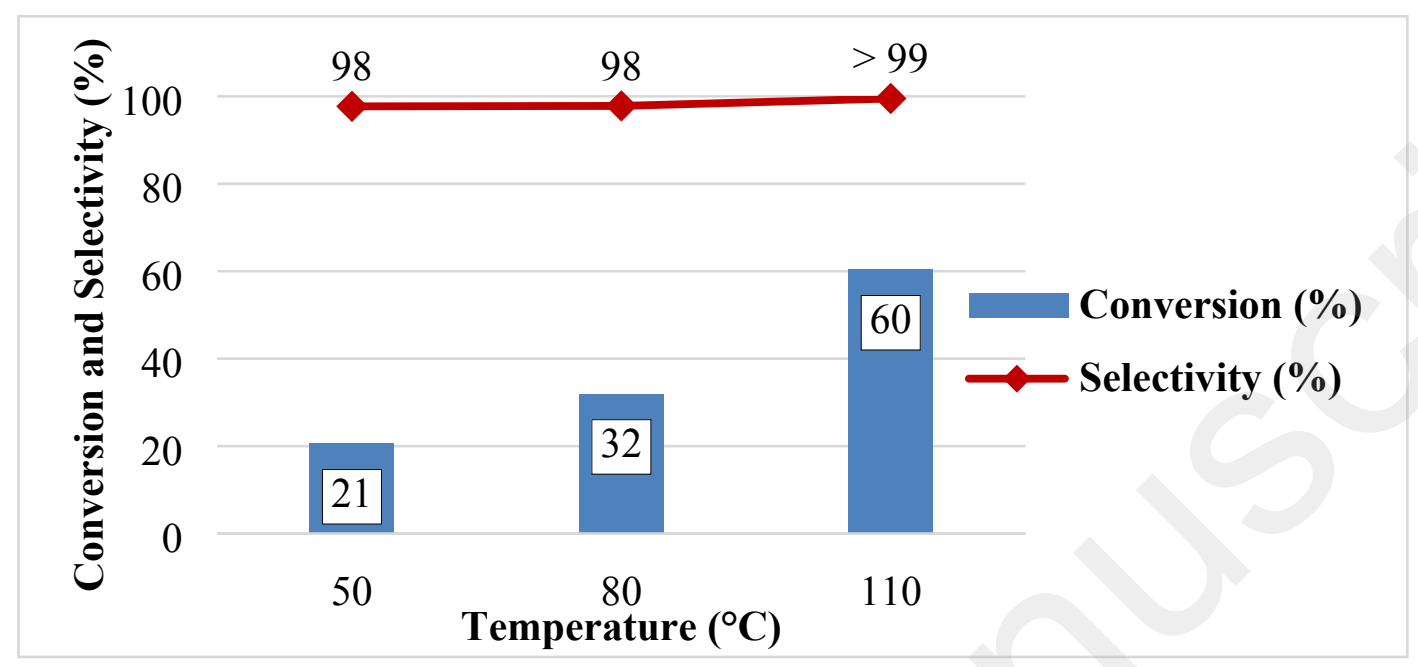

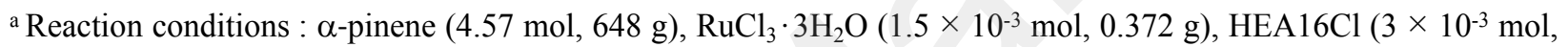
$1.04 \mathrm{~g}), \mathrm{H}_{2} \mathrm{O}(120 \mathrm{~g}), \mathrm{S} / \mathrm{M}=3000,1000 \mathrm{rpm}, 10$ bar of $\mathrm{H}_{2}$, 7h. Conversion and selectivity determined by Gas Chromatography

b) Influence of the pressure under $50^{\circ} \mathrm{C}$

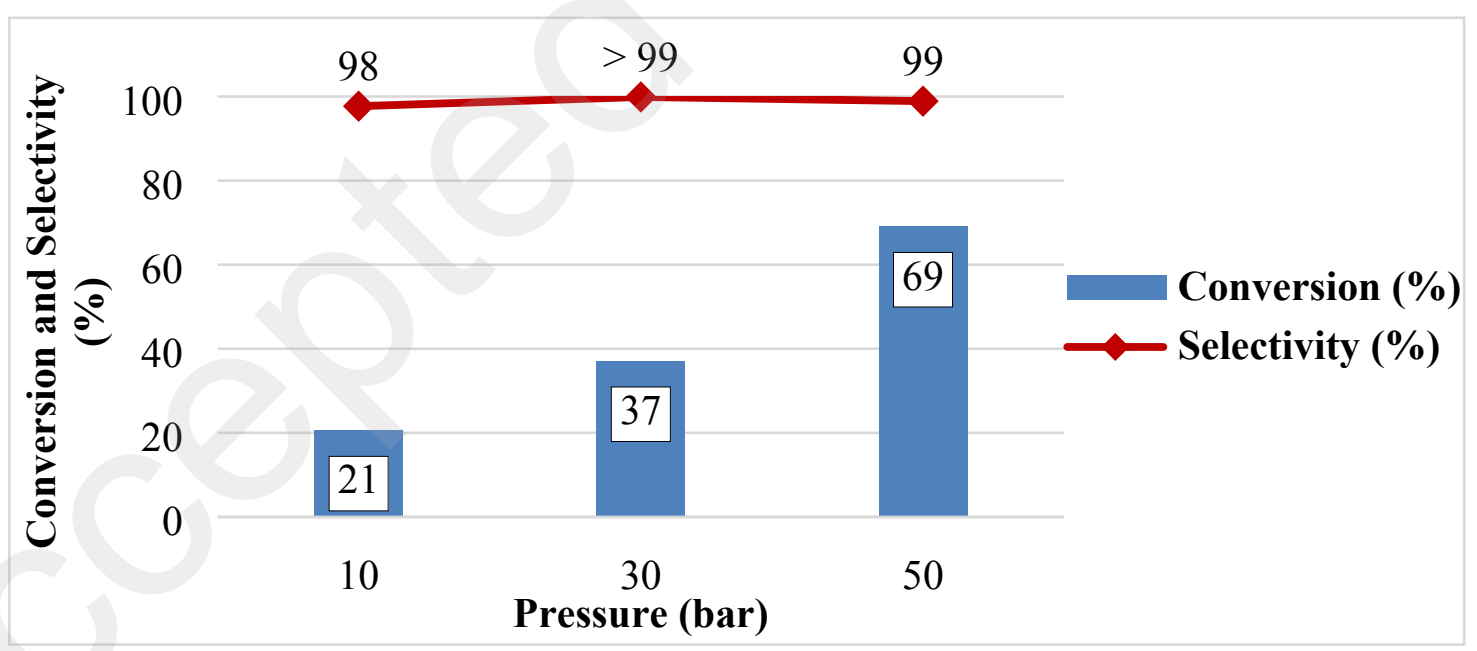

${ }^{a}$ Reaction conditions : $\alpha$-pinene $(3.81 \mathrm{~mol}, 540$ g. $), \mathrm{RuCl}_{3} \cdot 3 \mathrm{H}_{2} \mathrm{O}\left(1.3 \times 10^{-3} \mathrm{~mol}, 0.310 \mathrm{~g}\right), \mathrm{HEA} 16 \mathrm{Cl}\left(2.5 \times 10^{-3} \mathrm{~mol}\right.$, $0.866 \mathrm{~g}), \mathrm{H}_{2} \mathrm{O}(100 \mathrm{~g}), \mathrm{S} / \mathrm{M}=3000,1000 \mathrm{rpm}, 50^{\circ} \mathrm{C}, 7 \mathrm{~h}$. Conversion and selectivity determined by Gas Chromatography 
At a pressure of 10 bar $\mathrm{H}_{2}$, an increase in the temperature of the $\alpha$-pinene hydrogenation from 50 to $110^{\circ} \mathrm{C}$ led to higher conversions at the same reaction time, affording cis-pinane with a $60 \%$ conversion in $7 \mathrm{~h}$ while maintaining an excellent selectivity superior to $99 \%$. However, at this temperature, a slight agglomeration of the nanoparticles could be observed, considering metal nanoparticles dispersed in water as a metastable system. ${ }^{[34]}$ At a temperature of $50^{\circ} \mathrm{C}$, higher conversions up to $69 \%$ in $7 \mathrm{~h}$ could be achieved while increasing the pressure up to 50 bar $\mathrm{H}_{2}$, with a relevant selectivity $(>99 \%)$ in the cis-diastereoisomer. Since both parameters have a beneficial effect on the catalytic activity, the reaction was finally carried out at $110^{\circ} \mathrm{C}$ and 30 bar of $\mathrm{H}_{2}$, leading to a complete conversion in $4.5 \mathrm{~h}$ with a $99 \%$ selectivity for a $540 \mathrm{~g} \alpha$-pinene batch.

Finally, based on these optimized reaction conditions $\left(110^{\circ} \mathrm{C}, 30 \mathrm{bar} \mathrm{H}_{2}\right.$, substrate/metal ratio of 3000), recycling experiments were also conducted on a $200 \mathrm{~g} \alpha$-pinene batch (Figure 7). At the end of the reaction, the cis-pinane was separated from the catalyst phase through a simple decantation and recovered through the sampling valve. And then, a new batch of substrate was introduced within the aqueous suspension of ruthenium nanoparticles and hydrogenated under the optimized reaction conditions. During the second run, similar catalytic performances were achieved with a $97 \%$ conversion and a $97 \%$ selectivity in $4 \mathrm{~h}$. In the third cycle, a drop in the conversion was observed but only by extending the reaction time to $9 \mathrm{~h}$, a complete conversion was restored with a 95\% selectivity for the following runs. This activity loss, which could have been hidden at high metal loadings, ${ }^{[35]}$ could be attributed to a visual slow agglomeration of surfactant-stabilized nanoparticles between cycles decreasing the specific metal area, probably due to high process temperature used. Therefore, in this industrial-scaled approach, the deactivation of the catalyst by a chemical poison has been discarded. 
Figure 7. Recycling runs

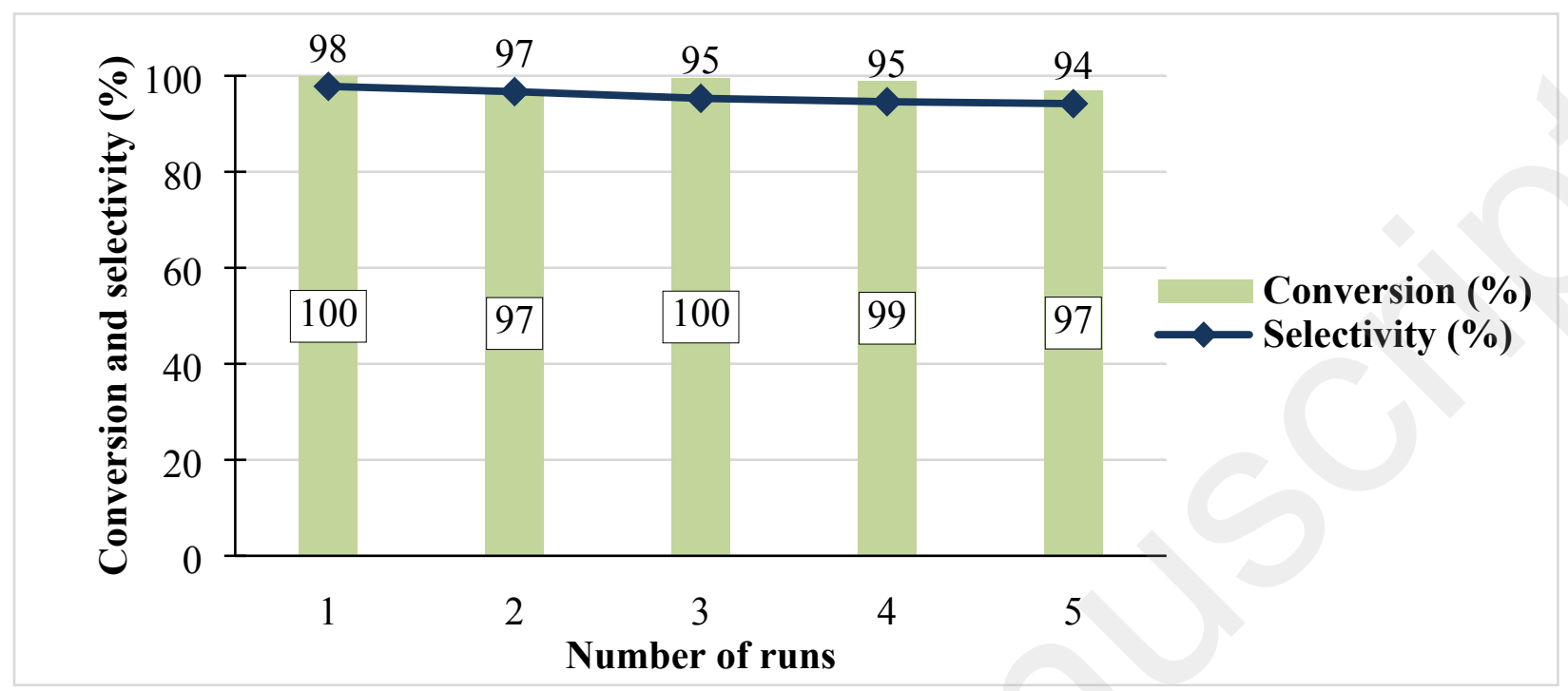

Reaction conditions: $\alpha$-pinene $(1.52 \mathrm{~mol}, 216 \mathrm{~g}), \mathrm{RuCl}_{3} \cdot 3 \mathrm{H}_{2} \mathrm{O}\left(0.51 \times 10^{-3} \mathrm{~mol}, 0.124 \mathrm{~g}\right), \mathrm{HEA} 16 \mathrm{Cl}\left(1 \times 10^{-3} \mathrm{~mol}\right.$, $0.352 \mathrm{~g}$ ), $\mathrm{H}_{2} \mathrm{O}(40 \mathrm{~g}), \mathrm{S} / \mathrm{M}=3000, \mathrm{w}=1000 \mathrm{rpm}, 30$ bar $\mathrm{H}_{2}, 110^{\circ} \mathrm{C}, 4 \mathrm{~h}$ (runs 1 and 2) and $9 \mathrm{~h}$ (runs 3-5) Conversion and selectivity determined by Gas Chromatography

Finally, the productivity of this catalytic system could be measured in term of turnover number (TON) defined as mole of desired product formed per mole of metal catalyst. Based on the total $\alpha$-pinene transformed, a total turnover number (TTON) of 14000 was achieved after five runs. To our knowledge, this value constitutes the best result defined in the literature (related to Table 1).

\section{CONCLUSION}

In summary, this study confirmed the potential of ruthenium nanoparticles stabilized in water by ammonium surfactants as an efficient catalyst for the selective hydrogenation of biosourced a-pinene into cis-pinane. Ruthenium nanoparticles were easily prepared in situ by chemical reduction under green and clean dihydrogen, in water as an inexpensive and environmentally benign solvent. Suitably designed with $\mathrm{HEA} 16 \mathrm{Cl}$ surfactant, these nanoparticles proved to be 
active, with complete conversion in $2 \mathrm{~h}$, and selective under mild conditions (10 bar of $\mathrm{H}_{2}$, room temperature). This process was scalable, showing good catalytic performances, in regards to the more efficient stirring of the pilot scale compared to the lab-scale. On a $540 \mathrm{~g}$ batch, $\alpha$-pinene was totally transformed in $4 \mathrm{~h} 30$ under 30 bar of $\mathrm{H}_{2}$ and at $110^{\circ} \mathrm{C}$, with a very low catalyst loading (0.033 mol\%) maintaining excellent selectivity towards cis-pinane (> 99\%). Through a biphasic liquid-liquid approach, the catalyst could be easily separated from the product by a simple decantation and recycled over several runs. These relevant results provide significant benefits in terms of yield, cost and environmental footprint and afford good prospects for industrial applications in the hydrogenation of hydrophobic alkenes.

\section{AUTHOR INFORMATION}

\section{Corresponding Author}

E-mail: Audrey.Denicourt@ensc-rennes.fr, $\underline{\text { Alain.Roucoux@ensc-rennes.fr }}$

\section{Funding Sources}

The authors declare no competing financial interest.

\section{ACKNOWLEDGMENTS}

This research project was supported by the ANRT ( $\mathrm{PhD}$ fellowship). The authors are indebted to Patricia Beaunier from Université Pierre et Marie Curie (UMPC) for Transmission Electron Microscopy analyses and to the Formulaction company (Toulouse) for the static multiple light scattering analyses conducted in their laboratory with the Turbiscan equipment 


\section{REFERENCES}

[1] Nuttens, N., Verboekend, D., Deneyer, A., Van Aelst, J. and Sels, B. F., Potential of Sustainable Hierarchical Zeolites in the Valorization of $\alpha$-Pinene. ChemSusChem 2015, 8 (7), 1197-1205; DOI: 10.1002/cssc.201403457

[2] Berger, R. G., Flavours and Flagrances - Chemistry, Bioprocessing and Sustainability, Springer-Verlag: Berlin Heidelberg, 2007; DOI: 10.1007/978-3-540-49339-6

[3] Swift, K. A. D., Catalytic Transformations of the Major Terpene Feedstocks. Top. Catal. 2004, 27 (1), 143-155; DOI: 10.1023/B:TOCA.0000013549.60930.da

[4] Golets, M., Ajaikumar, S. and Mikkola, J.-P., Catalytic Upgrading of Extractives to Chemicals: Monoterpenes to "EXICALS". Chem. Rev. 2015, 115 (9), 3141-3169; DOI: $10.1021 / \mathrm{cr} 500407 \mathrm{~m}$

[5] Mäki-Arvela, P., Holmbom, B., Salmi, T. and Murzin, D. Y., Recent Progress in Synthesis of Fine and Specialty Chemicals from Wood and Other Biomass by Heterogeneous Catalytic Processes. Catal. Rev. 2007, 49 (3), 197-340; DOI: 10.1080/01614940701313127

[6] Tanielyan, S., Biunno, N., Bhagat, R. and Augustine, R., Anchored Wilkinson Catalyst: Hydrogenation of $\beta$ Pinene. Top. Catal. 2014, 57 (17), 1564-1569; DOI: 10.1007/s11244-0140332-2

[7] Wang, L., Guo, H., Chen, X., Chen, Q., Wei, X., Ding, Y. and Zhu, B., Optimization of the catalytic hydrogenation of terebinth by a Ni-based catalyst. Catal. Sci. Technol. 2015, 5 (6), 3340-3351; DOI: 10.1039/C4CY01704H

[8] Ren, S., Qiu, J., Wang, C., Xu, B., Fan, Y. and Chen, Y., Influence of Nickel Salt Precursors on the Hydrogenation Activity of $\mathrm{Ni} / \gamma-\mathrm{Al}_{2} \mathrm{O}_{3}$ Catalyst. Chin. J. Catal. 2007, 28 (7), 651-656; DOI: 10.1016/S1872-2067(07)60056-4

[9] Xie, L., Wang, X., Yu, F., Yuan, B., Xie, C. and Yu, S., Preparation of cis-pinane via $\alpha-$ pinene hydrogenation in water by using Ru nanoparticles immobilized in functionalized amphiphilic mesoporous silica. RSC Adv. 2017, 7 (81), 51452-51459;

DOI: $10.1039 / \mathrm{C} 7 \mathrm{RA} 09865 \mathrm{~K}$

[10] Selka, A., Levesque, N. A., Foucher, D., Clarisse, O., Chemat, F. and Touaibia, M., A Comparative Study of Solvent-Free and Highly Efficient Pinene Hydrogenation over Pd on Carbon, Alumina, and Silica Supports. Org. Process Res. Dev. 2017, 21 (1), 60-64; DOI: 10.1021/acs.oprd.6b00344

[11] Simakova, I. L., Solkina, Y., Deliy, I., Wärnå, J. and Murzin, D. Y., Modeling of kinetics and stereoselectivity in liquid-phase $\alpha$-pinene hydrogenation over Pd/C. Appl. Catal. Al 2009, 356 (2), 216-224; DOI: 10.1016/j.apcata.2009.01.006

[12] Canova, L. A. Selective Hydrogenation of Alpha-Pinene to Cis-Pinane. US 1976-690558, 1976.

[13] Denicourt-Nowicki, A. and Roucoux, A., Metal Nanoparticles for Catalysis, Tao, F. F., Ed. The Royal Sociey Of Chemistry: Cambridge, 2014; DOI: 10.1039/9781782621034

[14] Hou, S., Xie, C., Yu, F., Yuan, B. and Yu, S., Selective hydrogenation of $\alpha$-pinene to cispinane over $\mathrm{Ru}$ nanocatalysts in aqueous micellar nanoreactors. $R S C A d v$. 2016, 6 (60), 5480654811; DOI: 10.1039/C6RA13099B

[15] Hou, S., Xie, C., Zhong, H. and Yu, S., Mild water-promoted ruthenium nanoparticles as an efficient catalyst for the preparation of cis-rich pinane. RSC Adv. 2015, 5 (109), 89552-89558; DOI: $10.1039 / \mathrm{C} 5 \mathrm{RA} 15283 \mathrm{~F}$ 
[16] Hou, S., Wang, X., Huang, C., Xie, C. and Yu, S., Highly Selective Hydrogenation of $\alpha-$ Pinene Catalyzed by Ru Nanoparticles in Aqueous Micellar Microreactors. Catal. Lett. 2016, 146, 580-586; DOI: 10.1007/s10562-015-1685-2

[17] Wang, X., Yu, F., Xie, C. and Yu, S., Highly selective hydrogenation of $\alpha$-pinene in aqueous medium using PVA-stabilized Ru nanoparticles. Mol. Catal. 2018, 444, 62-69; DOI: 10.1016/j.mcat.2017.10.020

[18] Qu, L., Yu, H., Yu, F., Yuan, B., Xie, C. and Yu, S., Catalytic reduction of $\alpha$-pinene using Ru nanoparticles stabilized by modified carboxymethyl cellulose. Appl. Surf. Sci. 2018, 453, 271279; DOI: 10.1016/j.apsusc.2018.05.083

[19] Denicourt-Nowicki, A., Ponchel, A., Monflier, E. and Roucoux, A., Methylated cyclodextrins: an efficient protective agent in water for zerovalent ruthenium nanoparticles and a supramolecular shuttle in alkene and arene hydrogenation reactions. Dalton Trans. 2007, (48), 5714-5719; DOI: 10.1039/B713989F

[20] Guyonnet Bilé, E., Sassine, R., Denicourt-Nowicki, A., Launay, F. and Roucoux, A., New ammonium surfactant-stabilized rhodium(0) colloidal suspensions: Influence of novel counteranions on physico-chemical and catalytic properties. Dalton Trans. 2011, 40 (24), 6524-6531; DOI: $10.1039 /$ C0DT01763A

[21] Da Silva, M. G. A., Meneghetti, M. R., Denicourt-Nowicki, A. and Roucoux, A., New and tunable hydroxylated driving agents for the production of tailor-made gold nanorods. RSC Adv. 2013, 3 (40), 18292-18295; DOI: 10.1039/C3RA42949K

[22] Hubert, C., Denicourt-Nowicki, A., Guégan, J.-P. and Roucoux, A., Polyhydroxylated ammonium chloride salt: a new efficient surfactant for nanoparticles stabilisation in aqueous media. Characterization and application in catalysis. Dalton Trans. 2009, (36), 7356-7358; DOI: 10.1039/B911094A

[23] Nowicki, A., Le Boulaire, V. and Roucoux, A., Nanoheterogeneous Catalytic Hydrogenation of Arenes: Evaluation of the Surfactant-Stabilized Aqueous Ruthenium(0) Colloidal Suspension. Adv. Synth. Catal. 2007, 349 (14-15), 2326-2330; DOI: . $10.1002 /$ adsc. 200700208

[24] Ohde, H., Wai, C. M., Kim, H., Kim, J. and Ohde, M., Hydrogenation of Olefins in Supercritical $\mathrm{CO}_{2}$ Catalyzed by Palladium Nanoparticles in a Water-in- $\mathrm{CO}_{2}$ Microemulsion. $J$. Am. Chem. Soc. 2002, 124 (17), 4540-4541; DOI: 10.1021/ja012232j

[25] Yan, N., Xiao, C. and Kou, Y., Transition metal nanoparticle catalysis in green solvents. Coord. Chem. Rev. 2010, 254 (9), 1179-1218; DOI: 10.1016/j.ccr.2010.02.015

[26] Bhattacharjee, S., DLS and zeta potential - What they are and what they are not? J. Control. Release 2016, 235, 337-351; DOI: 10.1016/j.jconrel.2016.06.017

[27] Mengual, O., Meunier, G., Cayré, I., Puech, K. and Snabre, P., TURBISCAN MA 2000: multiple light scattering measurement for concentrated emulsion and suspension instability analysis. Talanta 1999, 50 (2), 445-456; DOI: 10.1016/S0039-9140(99)00129-0

[28] Tisserand, C., Brambilla, G., Meunier, G. and Parker, A., Predicting the long-term stability of depletion-flocculated emulsions by static multiple light scattering (SMLS). J. Disper. Sci. Technol. 2019, 1-8; DOI: 10.1080/01932691.2019.1610424

[29] La Sorella, G., Strukul, G. and Scarso, A., Recent advances in catalysis in micellar media. Green Chem. 2015, 17 (2), 644-683; DOI: 10.1039/C4GC01368A

[30] Albuquerque, B. L., Denicourt-Nowicki, A., Mériadec, C., Domingos, J. B. and Roucoux, A., Water soluble polymer-surfactant complexes-stabilized $\mathrm{Pd}(0)$ nanocatalysts: Characterization 
and structure-activity relationships in biphasic hydrogenation of alkenes and $\alpha, \beta$-unsaturated ketones. J. Catal. 2016, 340, 144-153; DOI: 10.1016/j.jcat.2016.05.015

[31] Scheeren, C. W., Machado, G., Teixeira, S. R., Morais, J., Domingos, J. B. and Dupont, J., Synthesis and Characterization of $\operatorname{Pt}(0)$ Nanoparticles in Imidazolium Ionic Liquids. J. Phys. Chem. B 2006, 110 (26), 13011-13020; DOI: 10.1021/jp0623037

[32] Léger, B., Denicourt-Nowicki, A., Roucoux, A. and Olivier-Bourbigou, H., Synthesis of Bipyridine-Stabilized Rhodium Nanoparticles in Non-Aqueous Ionic Liquids: A New Efficient Approach for Arene Hydrogenation with Nanocatalysts. Adv. Synth. Catal. 2008, 350 (1), 153159; DOI: $10.1002 /$ adsc.200700341

[33] Pélisson, C.-H., Hubert, C., Denicourt-Nowicki, A. and Roucoux, A., From Hydroxyalkylammonium Salts to Protected-Rh(0) Nanoparticles for Catalysis in Water: Comparative Studies of the Polar Heads. Top. Catal. 2013, 56 (13), 1220-1227; DOI: 10.1007/s11244-013-0088-0

[34] Aiken, J. D., Lin, Y. and Finke, R. G., A perspective on nanocluster catalysis: polyoxoanion and (n-C4H9)4N+ stabilized $\operatorname{Ir}(0) \sim 300$ nanocluster 'soluble heterogeneous catalysts'. J. Mol. Catal. A 1996, 114 (1), 29-51; DOI: 10.1016/S1381-1169(96)00302-0

[35] Gladysz John, A., Recoverable catalysts. Ultimate goals, criteria of evaluation, and the green chemistry interface. Pure Appl. Chem. 2001, 73 (8), 1319-1324; DOI: 10.1351/pac200173081319 


\section{Graphical abstract}

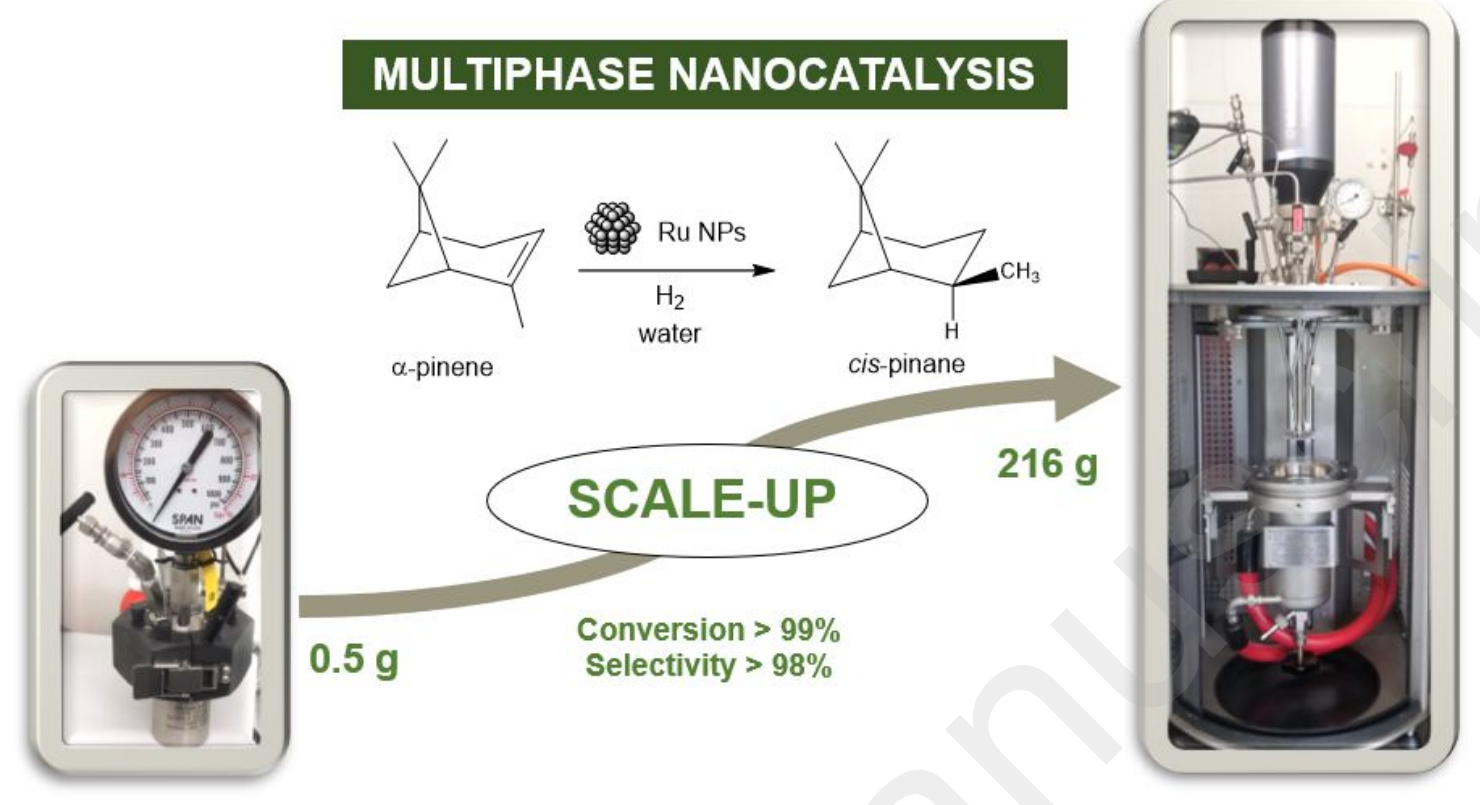

\section{Synopsis}

The selective hydrogenation of $\alpha$-pinene into cis-pinane was industrially scaled-up, using reusable aqueous suspensions of ruthenium( 0 ) nanoparticles, stabilized with an ammonium surfactant. 